\title{
Leprosy in the Luapula Valley, Zambia: History, Beliefs, Prevalence and Control
}

P. GLYN GRIFFITHS, M.G., B.sc., м.B., ch.B., M.R.c.P.(London), M.R.c.P.(Glasgow) (Medical Superintendent, Liteta Leprosarium and Lua pula Leprosy Settlement, and Leprologist, Republic of Zambia)

\section{The Luapula Valley}

The Luapula River drains the swamplands of Lake Bangweulu on the Central African Plateau (Map 2), and, sweeping round to the North, flows into Lake Mweru, which at Pweto empties itself into the River Luvua, a tributary of the great Congo River system.

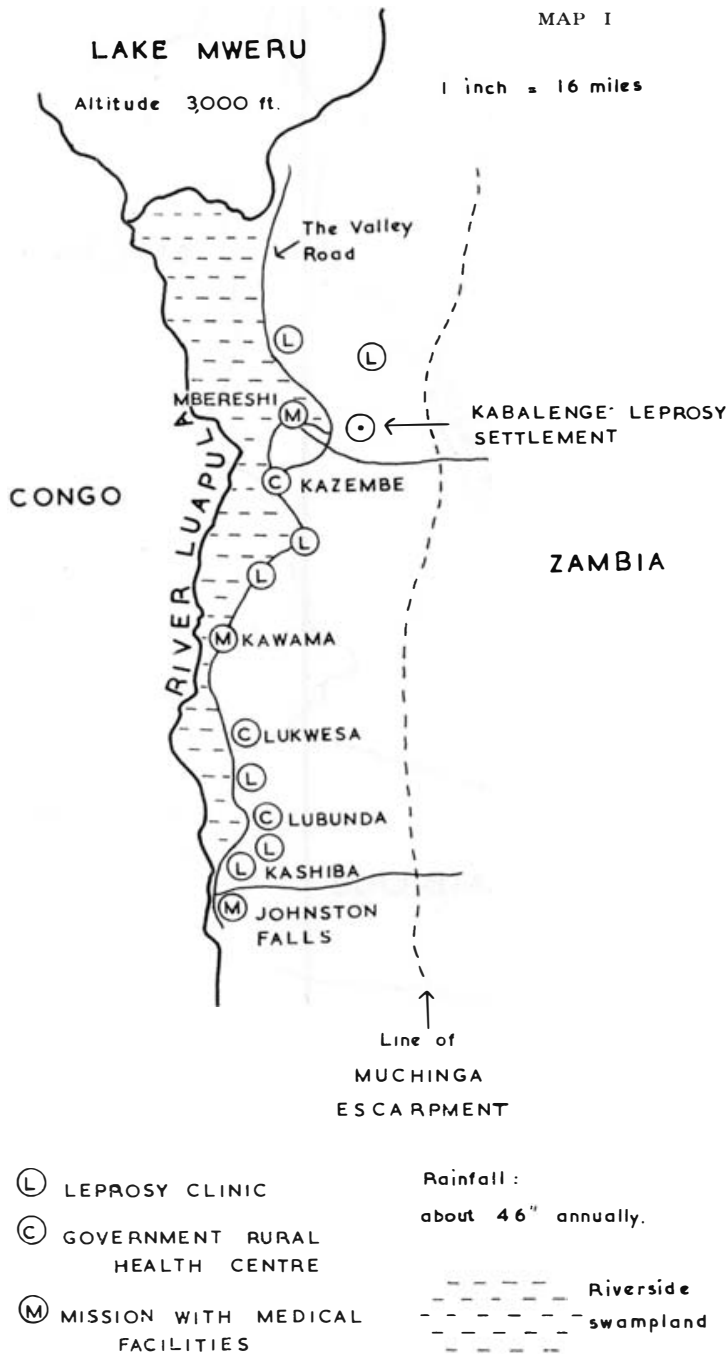

This paper considers leprosy amongst the people living along the East bank of the Luapula River for the sixty-odd miles between Johnston Falls and the town of chief Kazembe of the Lunda (Map I).

\section{Population}

In this small area there is, for Zambia, an unusually high concentration of inhabitants. The Census taken in I963, and the Registration of electors in the same year, offer accurate population figures, and there are some $2 \mathrm{I}$, OOO persons over 2 I years of age living in the area. This is a very different state of affairs from that prevailing in the greater part of the rural areas of Zambia; for the most part the Zambian rural population is very sparsely distributed, at only about eight per square mile, all ages. In the 600 square miles under consideration here, the adult population density is 35 per square mile! In fact, the population is much more concentrated than this suggests, as the people inhabit large villages, of a median range of 20 to 30 houses, ranging up to $\mathrm{I} 45$ houses, and in the case of Kazembe's town, over i, ooo. Only about an eighth of the villages lie off the main swampmargin road (Cunnison, I959).

As one travels along this road, which links Kazembe's town with Johnston Falls, village succeeds village along the road side, so that it is often difficult to know where one village ends and the next begins.

The North Luapula constituency is identical with the area chosen for this investigation; thus it was possible to check the register of voters against the Census figures. Practically every single person over the age of 2 I years registered for the election (which was the first under universal suffrage), so it is believed that the $9^{6} 63$ population figures used here are remarkably accurate.

Population growth has been very rapid-from 27,154 in 194 I to over 5 I, Ooo in 1963 (all ages). 


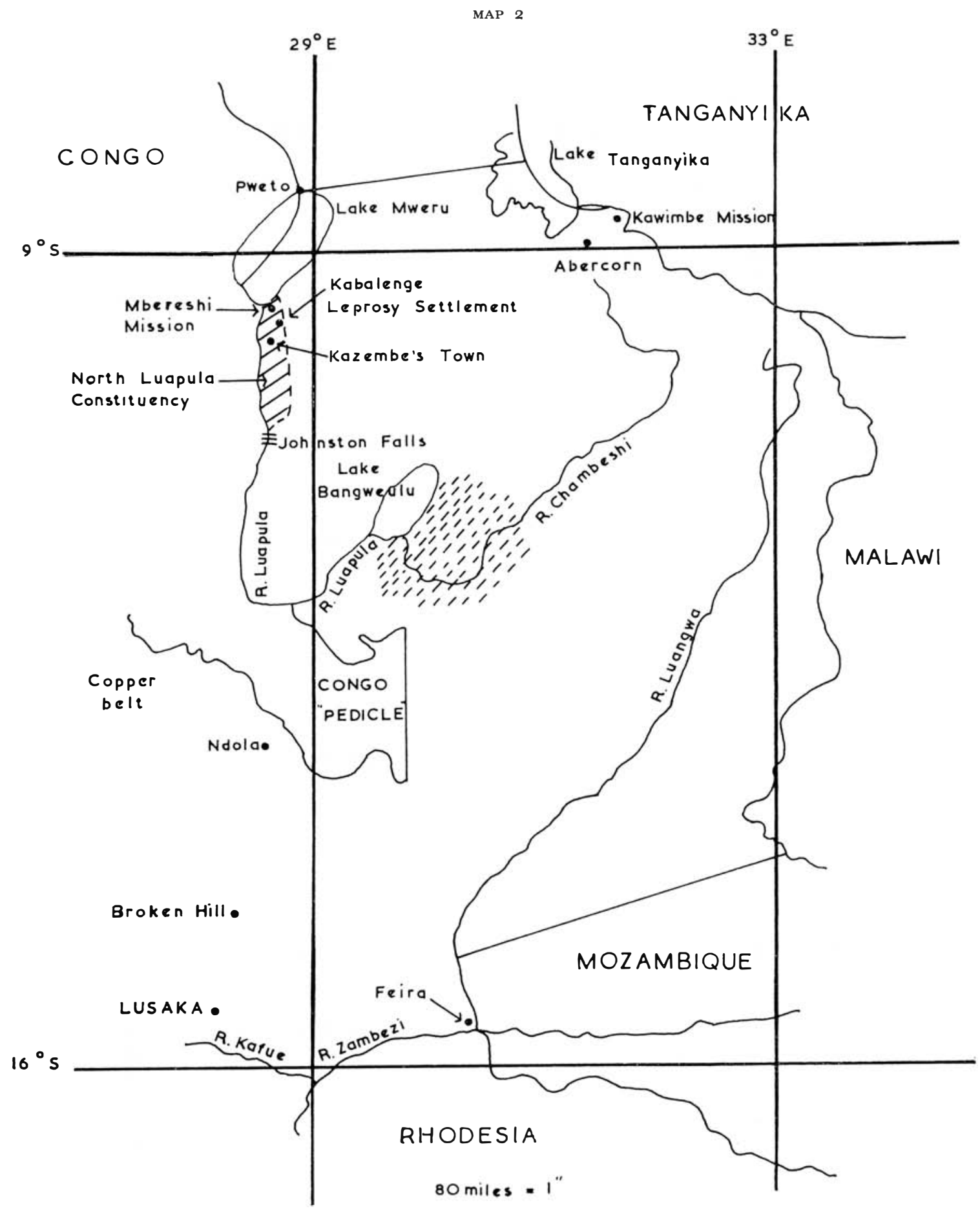

6 Leprosy Review 
In 1963 there were Io I persons under 2 I years of age for every 70 over that age.

About 25 per cent of the adult males are away from the valley at any one time, as they go in large numbers to the Copperbelt to seek work. Many stay away from their villages for very many years; some leave the valley for only a year or two at a time.

The people are of the 'Luapula Type', Kazembe Lunda (or Luunda), and Chishinga, who are groups of the Central Bantu, Northern Division (Mitchell, I960).

\section{Historical Background}

The date of the establishment of chief Kazembe's overlordship in the Luapula Valley is known fairly accurately. Lacerda visited Kazembe's town in 1798 , and recorded that the dynasty had been there for about fifty years at that time (Cunnison, I959).

The Lunda chief Kazembe and his followers had come to the Luapula from the great Mwata Yamvo kingdom in the middle Congo; they conquered peoples such as the Bwile and Shila whom they found living in the valley.

The Congo (Leopoldville), from which Kazembe and his people came, has a high prevalence of leprosy. There were 275,000 cases under treatment in the Congo in 1956 , or 20 per I, ooo of the population (WHO, I 959).

In the fascinating Report on Leprosy produced by the Royal College of Physicians of London in I 867, Gavin Milroy, Secretary of the College's Leprosy Committee, contributed a 'Sketch of the Geographical Distribution of Leprosy'. (It was this report which discredited entirely the belief that leprosy was contagious, and was regarded by the Editor of The Lancet ( 1867 ) as 'the authority' on leprosy of the time!) Milroy writes:

'The chief seats of leprosy in recent times continue to be the same regions of Africa and Asia where it was originally seen, and where it was known to have been most common in remote ages.'

He mentions that slaves brought to the West Coast of Africa from the interior 'are frequently affected with the disease'.

There is no doubt that slaves were taken from the Luapula Valley to the West Coast; many of these slaves were obtained by Portuguese and Arab slave-traders with the aid of Kazembe
(Cunnison, I959), and some of those slaves to whom Milroy refers may possibly have come from the Luapula, therefore.

In the same Report, Mr Bradshaw, Colonial Surgeon in Sierra Leone, commented that leprosy was particularly common in 'natives who come from the Niger and Congo neighbourhoods'.

The origins of leprosy remain a mystery; Rogers (I924) connected the high prevalence rates in Central Africa to an Egyptian record of I $35^{\circ}$ B.C. of leprosy among negro slaves from the Sudan and Dafur. But Feeny (I964) considers that early 'knowledge' of leprosy in Africa was probably 'supposition'. Mфller-Christenson ( 1963 ) examined many thousands of mummies and skeletons from ancient Egypt and Palestine, and found no evidence of leprosy earlier than about A.D. 500.

\section{Traditional Beliefs about Leprosy}

That leprosy is, in fact, a disease long known amongst the people of the Luapula Valley appears to be confirmed by the many words in their language which they use to describe it. (Lunda, which is akin to Bemba, is the language mostly in use.)

Thus there is a word for leprosy in general: 'tembwe', almost a euphemism; this word covers all manifestations of the disease. A single patch of diseased skin caused by leprosy is 'chibashi'. Skin thickening due to leprosy is 'mamombo'; the nodular form is 'mapumba'; the blistering often noticed early in the course of the disease is 'mavovela' or 'matutulu'. 'Kaswandala' describes the patient with only one or a few skin patches, with or without coincident loss of the fingers. 'Mamombe' rather more definitely defines as leprosy the skin patches, and 'mumba' identifies lepromatous skin nodules, with the connotation (associated with others of these disease-names) that it is a disease which leads inevitably to gross deformity through the loss of fingers or toes.

There is a proverbial saying: 'Nsala ni mamombo tayalila apepi' . . . hunger is like leprosy, it doesn't kill quickly'.

There is a considerable volume of folk-lore and traditional belief associated with the disease:

The disease was often believed to be a punishment (how reminiscent of Mediaeval Europe!) : 
(a) It might be caused by theft, especially by stealing an animal or a fish taken from someone else's trap. The owner of the trap would put a special 'medicine' into the trap to cause leprosy in the thief.

(b) Or it could be caused by adultery; the aggrieved husband could, by arrangement with a worker-of-spells, cause leprosy to attack the offender.

(c) Eating the flesh of certain animals, especially the hippopotamus, caused leprosy in some people. This was sometimes thought to be due to the spirit of a person dying with leprosy having taken up residence in the hippo. (This belief spreads as far South as to the Feira District on the Zambesi, where the Chikunda people live, and I have had patients from Feira who believed their leprosy was due to eating hippo.) Kazembe himself never ate any of the larger animals such as elephant, hippo, or eland, because they were his 'fellow-chiefs of the bush' (Cunnison, I 959).

Witchcraft was believed to be an important cause of leprosy, but was thought to be incurred sometimes by such foolish behaviour as insolence to an old and respected member of the community.

When someone with leprosy died, he was not buried but his body was covered in thick bark, and either thrown into a cave or pit, or put up into a tree in the way that a leopard stores his kill. Should anyone be foolish enough to bury the patient, the leprosy would pass to the gravedigger.

Eating guinea-fowl, bushbuck, bubble fish, any kind of red or scaleless fish (e.g. 'Sampa') makes leprosy worse. The disease being red in colour on the skin, red things as a whole tend to aggravate the leprosy.

The symptomatology of leprosy is well known to the rural people. Before the leprosy makes itself manifest on the skin, the patient suffers 'kunanuna' (formications), and 'kubaba' (itching without actually wanting to scratch). This is a very good description of prodromal symptoms often seen in leprosy. Patients from areas of high prevalence, such as the Luapula Valley, know the disease well, and to this day they speak of having suspected that they had leprosy when they had these prodromata, 'before the leprosy showed itself on my skin, when I felt it inside my body'.
Remedies used by the village herbalists (the 'shinganga') are many. For a localised patch (tuberculoid type) multiple scarification with the application of a caustic is commonly carried out; for more widespread types, such as the lepromatous type, lotions and also herbal potions are used. Often enough no actual 'practitioner' is called upon, as many of the older people know which kinds of herb, bark, etc., are usually used to make up these 'cures'.

Diagnosis of leprosy is usually very promptly made by the older people in a village community and is often made also by the 'shinganga' if someone goes for treatment with some ailment not yet knowing that he has leprosy. Surprisingly, rarely are the people wrong in their diagnosis. All too often I see patients who knew well that they had leprosy, but could not persuade the staff at hospital to accept the diagnosis! Many of the older generation of 'shingangas' (who, by the way, are very far from being 'witchdoctors') are very honest practitioners, and accept no fee in the event of their failing to effect a cure; some of them around the Liteta area send any new leprosy which they see direct to the Leprosarium for treatment! Some, again, distinguish between types of leprosy which they feel that they can treat successfully (e.g. one or two isolated patches only) and types which they know from experience will get worse under their treatment (e.g. nodular lepromatous disease). They maintain their reputation in the treatment of leprosy from those cases of tuberculoid disease which are probably in any event self-healing, as so of ten in this type their local scarification of the skin is followed by apparent cure.

Isolation: there was, in addition to the beliefs mentioned above, a generally accepted notion of the contagiousness of leprosy. Old people tell me that, around the turn of the century, segregation was quite rigidly practised when someone was obviously severely attacked by leprosy (this usually meant that the patient had gross tissue loss of hands or feet, and often enough such a patient was probably not infectious at all). The sufferer had to live in a hut by himself, far from the village, and to its West (the prevailing wind being from the East). Anyone kind enough to take food to the patient should be a spinster or a widow, and, when taking the food, should walk backwards, so as 
not to see either the patient or his hut. The food used to be left halfway between the village outskirts and the 'isolation hut'. Small wonder that, under these conditions, people isolated for leprosy often died of hunger. They were never slain, because it was believed that the man who killed someone with leprosy would himself contract the disease.

Many of the beliefs recounted above are still to be found amongst the older generation; but the segregation system was discarded around I9I5 to I920 with the increasing influence of the Missions and of the Central Government.

Amongst some of the younger generations, a depressing apathy succeeded the old beliefs, and many came to think of leprosy as an act of fate, for which nothing much could be done either in the way of treatment or of control.

In I9I 5 the London Missionary Society formed a small 'isolation camp' at Mbereshi, near Kazembe's town. Its modern successor is the Luapula Leprosy Settlement at Kabalenge, near Kawambwa, on the escarpment just above the valley itself, which was started by $\mathrm{Mr} \mathrm{W}$. Densham, a B.L.R.A. worker, as a joint government and mission enterprise in 1944 . By the end of 1963 nearly 6,500 patients had been admitted there. (Many of those admitted came from other Districts and Provinces of Zambia.)

This change in the approach to leprosy is reminiscent of Latapi (quoted by Frenken, I 963) :

'He who threw stones at the leprosy sufferer, making him flee, did a primitive and barbaric sanitary work. But the first man who took him in, nursed him, and looked after him, was a precursor of our Christian Society.' It was in fact the Christian Missions which first undertook the care and isolation of leprosy in Zambia.

\section{Early Historical References to Leprosy in Zambia}

The earliest record of leprosy in Zambia which I have been able to find is by Livingstone (quoted in Gelfand, I957). Amongst patients seen by Livingstone at Naliele (Barotseland) was a man 'seized by a species of leprosy called Mbingwa which soon produces ankylosis of the joints'. As all the medicines he had tried from the local practitioners had failed to cure him, this man attempted to end his life by thrusting a spear into the hollow above his collar bone (Gelfand, 1957). (The word 'Mbingwa' is still the one used most widely for leprosy by the peoples of Barotseland).

In I 869, Livingstone recorded seeing much leprosy on his journey from Ujiji into the Congo (Gelfand, I957); in that journey he was travelling through country not very far from the Luapula.

Sekeletu, son of Sebituane of the Makololo, then the rulers of Barotseland, was said to have been 'carried off by leprosy' (Gelfand, i 96i), though Livingstone had diagnosed pemphigus when he examined him.

In I 893 Dr C. B. Mather, of the London Missionary Society, founded the first leprosy settlement in Zambia, at Kawimbe, near Lake Tanganyika. Dr Mather wrote in a report to London:

'I rejoice to chronicle the building and occupation of a small hamlet, outside the village, for outcasts suffering from a disease resembling leprosy. There are seven houses in it, and some twenty people living in them at present'. (Gelfand, I 96i).

There is to this day a very well run leprosy settlement run by the Mission at Kawimbe.

In igo8, F. W. Worthington, Secretary of Native Affairs with the Chartered Company, reported that in the 'Batoka district' (part of the Southern Province of Zambia) leprosy had an incidence of $2 \mathrm{I} .5$ per $\mathrm{I}, 000$, and in the Sesheke District of Barotseland 25.4 per I, ooo (Gelfand, I96 I).

\section{Modern Scientific Reports on Leprosy in Zambia}

Cochrane visited the country in I 932 , and stated 'it is known that certain areas of this territory, e.g. Barotseland, are centres of a very high incidence of leprosy. If, as there appears to be, about I per cent of the population around Livingstone either suffering from leprosy or its effects, the percentage in Barotseland must be staggering'. (Cochrane, I932). (He was indeed correct - in July I964, 6,33 I persons were registered on the Barotseland Leprosy Register out of an adult population of I 87,400 - or 34 per I, OOO).

In I940 Muir visited Zambia. He quotes 'official figures' (based upon tax exemption statistics) for the year i 934. These varied from I 3. I per I, ooo in Barotseland to 0.73 per I, ooo in the Eastern Province, with a total of 6,748 
leprosy patients in an estimated population of I, 334, 465 , or 5.2 per I, ooo (Muir I 940). These figures only took into account those persons deemed unfit to work to collect their tax money, and this decision was made by administrative officers, whose estimation of disability probably varied very much. When Muir visited this country, he noted that the whole number of patients provided for by institutions was 'not more than two hundred and fifty'. This was a far cry from today's situation. In December, I 963 , there were I 5,300 leprosy patients actually under treatment in the whole of Zambia, 4,500 odd of these being in nine Government and $2 \mathrm{I}$ Mission Leprosy Settlements, the remainder attending at some $35^{\circ}$ treatment centres as out-patients.

In 1949, Sister Elsie Baker, of the London Missionary Society's Leprosy Settlement at Kawimbe (founded in I 893, vide supra), carried out a leprosy survey along the Southern shore of Lake Tanganyika in the Abercorn District. She examined 4,670 people, and found that 75 (I6 per I, Ooo) had leprosy. She reported, however, that there was 'a gross concealment of cases' in the area. (Baker, I 949).

During April to June i950 the first major leprosy survey in Zambia was carried out by Ross Innes. In a sampling survey, he examined 27,9 I 5 persons, and found an average prevalence of I 2.6 per I, ooo. He found prevalence to be much the highest in the Luapula Valley; but he was not able to extend his survey beyond the Northern, Eastern, and Southern Provinces, and so did not visit Barotseland. Only i 8 per cent of the new leprosy which he diagnosed was amongst children. (By r949 Ross Innes found that there were I,7I 4 patients isolated in eight leprosaria, and that 295 new cases were reported during that year). (Ross Innes, I950 and I95I, and Pizzi, I 952.)

In the North Luapula Constituency of the Luapula Valley Ross Innes found prevalence rates as follows:

Chief Kazembe's area: 25 per I, ooo in Musanda sub-area

I 7.3 per I, ooo in Mwansabombwe area

Chief Lukwesa's area: 25.6 per I, ooo

Chief Lubunda's area: 20.6 per I, ooo

Chief Kashiba's area: I9. I per I, ooo
I IO cases of leprosy were found amongst 5,3 I9 persons examined, or 20.7 per 1,000 , in the whole of this Valley area (figures abstracted from Ross Innes, I950).

In addition, there were many patients from the areas of these four chiefs already under treatment at the Kabalenge Leprosy Settlement. Records for that period are incomplete, but I have been able to trace 56 adult admissions from the area to the Settlement, all of whom were in-patients at the time of Ross Innes' survey. (This gives a figure of half as much again for the prevalence of the disease, if one ignores the fact that Ross Innes was able to examine only 5 , ooo odd of the more than 30 ,ooo persons of all ages in the area in the year of the survey.)

Ross Innes concluded that the picture was of 'a moderately severe, but widespread leprosy of ancient origin, which is nowadays slowly but surely increasing'.

$\mathrm{He}$ made a number of detailed practical recommendations to the then Director of Medical Services, including the following:

(I) The purchase and free issue of the Sulphone drugs.

(2) The appointment of a territorial leprologist. (3) The strengthening, encouragement and enlargement of the regional leprosaria.

(4) The establishment of a new 'central' leprosarium.

(5) The avoidance of compulsion and rigid repressive legislation in leprosy.

(6) The development of the 'outward' look in all existing and future leprosaria.

In December i 952, Cochrane visited Zambia for the second time, and he fully supported the policy advised by Ross Innes.

It is gratifying to be able to report that all six of Ross Innes' recommendations have been carried out; though the sixth has only been followed through by certain of the leprosaria in the territory (notably Chitokoloki, Luampa, Fiwila, Kawimbe, Chikankata, Liteta, and, as will be related here, most notably from the Luapula Leprosy Settlement, Kabalenge, Kawambwa).

J. T. Worsfold ( 1957), working in the NorthWestern Province of Zambia, found a prevaler;e of I I.85 per I, Ooo in a most detailed intr. sive survey covering $20,14^{8}$ people in the Jalovale District. In $195^{8}$ Worsfold reported a decline in 
leprosy in the same area, and he concluded that this decline had begun before the introduction of sulphone therapy.

\section{Garrod's Campaign in the Luapula Valley}

(This rather odd sub-title may remind the reader of 'Jeb Stuart in the Shenandoah Valley', and it had something in common with that famous cavalry campaign, being hard-hitting, energetic, and enthusiastic, but with much longer lasting and more fruitful results than the short whirlwind campaign of the secessionist general.)

In February 1954 Dr J. M. B. Garrod (later Director of the East African Leprosy Research Centre at Alupe) took up duties at the Luapula Leprosy Settlement, Kabalenge, as its first Medical Superintendent, and as the territory's first leprologist.

Prior to his arrival Mr L. W. Corbridge had been lay Superintendent of the Settlement since I 946 . He had been trained as a B.L.R.A. worker by A. B. MacDonald in Itu, Nigeria, and had already laid the ground for an 'outward looking' approach to the leprosy problem in the valley. Several small leprosy clinics had been set up along the valley road for out-patient treatment of patients whose treatment had been stabilised at the main settlement at Kabalenge, where a male nurse $\mathrm{Mr}$ Spengeler had been added to the staff.

The local authorities (the chiefs and their councillors) were persuaded to construct, at no cost to the Government Medical Department, seven clinics along the valley floor in the most densely populated areas which had no Government or Mission general medical clinic. In addition, the local authorities agreed to build houses for clressers seconded firom the Leprosy Settlement to man these clinics. These 'Leprosy Clinics' were additional to the three Mission Medical treatment centres (Mbereshi, Kawama, and Johnston Falls) and the three Government Rural Health Clinics (at the towns of Chiefs Kazembe, Lukwesa and Lubunda) already in existence (Map 2).

Thus, in addition to the 'parent' Settlement at Kabalenge, there were i 3 treatment centres along the sixty mile strip of valley bottom where there had been shown to be (by Ross Innes) such a high prevalence of leprosy.
The dressers who manned the leprosy clinics were trained in the basic principles of diagnosis and treatment of leprosy at the Kabalenge Settlement before being posted to their new stations. Each dresser spent two days in each week giving out Dapsone tablets to the patients for whom he was responsible. (Injectable 'Avlosulfon' given once every two or four weeks is now used instead). During the remainder of the week, the dressers visited the villages in their area on foot or by bicycle, examining contacts, seeking new cases, and following up any patients who had failed to attend regularly for treatment. Each of the treatment centres was visited at intervals of not more than three months by staff from the Kabalenge Settlement; at each of these visits the patients at the out-patient treatment centres were clinically reviewed, and newly discovered patients examined. A close liaison was maintained with the local authorities, particularly with regard to any patients who defaulted from treatment; and the respect in which the Officers of the chiefs was held was sufficient, without invoking any laws, to persuade most defaulting patients to return to regular treatment.

This system has been continued ever since I954, and attendance at the clinics is still excellent, thanks to the co-operation of the local authorities.

\section{The Results of the Campaign}

The projected eradication campaign by B.L.R.A. to be carried out in Malawi in the near future, makes this an appropriate time to offer the results of this relatively simple campaign in an area of high leprosy prevalence.

TAB LE I

North Luapula Constituency, Kawambwa District, Zambia

(i.e. the areas of Chiefs Kazembe, Lukwesa, Lubunda and Kashiba)

Adult population, I963: 2 I, ooo

Total population, I963: 5 I, ooo

Total adults treated for leprosy, i 953-i963: I, 8 I 5

Prevalence of leprosy: $\quad 86$ per I, ooo adults 36 per i, ooo all ages 
TABLE II

$\mathcal{N}$ ew Cases of Leprosy attending for treatment for the first time: I 953-I963 (adults)

\begin{tabular}{|c|c|c|c|}
\hline $\begin{array}{l}\text { I 953: } \\
\text { I954: }\end{array}$ & $\begin{array}{c}88 \\
459^{*}\end{array}$ & \multicolumn{2}{|c|}{$\begin{array}{l}\text { Totals for the eleven year } \\
\text { period from each chief's area: }\end{array}$} \\
\hline I955： & $\begin{array}{l}459 \\
323\end{array}$ & & \\
\hline I956: & 203 & Kazembe: & 525 \\
\hline I 957: & I 64 & Lukwesa: & 368 \\
\hline I958: & I I 6 & Lubunda: & 505 \\
\hline I959: & IOO & Kashiba: & 417 \\
\hline ig6o: & I 23 & & \\
\hline I96 I : & I 08 & & I, 8 I 5 \\
\hline $\begin{array}{l}\text { I } 962: \\
\text { I } 963:\end{array}$ & $\begin{array}{l}71 \\
60\end{array}$ & & \\
\hline & 15 & & \\
\hline
\end{tabular}

*Since I954, when the campaign was started, and in which year nearly one quarter of all the treated cases were first brought under treatment, there has been an annual reduction in the number of new cases found.

From 1956 on the annual reduction bears a remarkably close resemblance to the 5 per cent annual decrease reported by Browne (1962) in Eastern Nigeria, where a similar campaign has been under way for a long time. Table Three illustrates this trend.

TABLE III

Annual Rates, new Leprosy, Luapula North

New Cases Expected new cases at a reduction by $\mathrm{I} 5 \%$ annually

\begin{tabular}{|c|c|c|}
\hline I 956: & 203 & \\
\hline I 957: & I 64 & I 70 \\
\hline I 958: & I 16 & I 45 \\
\hline I 959: & IOO & I 23 \\
\hline I 96o: & I 23 & IO5 \\
\hline I 96 I : & 108 & 90 \\
\hline I $962:$ & $7 I$ & 77 \\
\hline I $963:$ & 60 & 66 \\
\hline
\end{tabular}

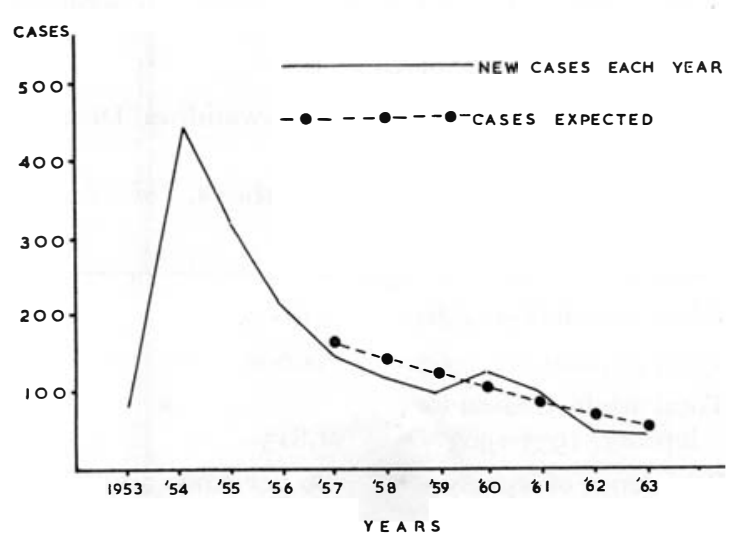

To show the numbers of new cases of leprosy brought under treatment annually, and to compare these figures with those which would be expected if there were an annual i 5 per cent decrease.

Tables one to three and the accompanying graph show the effect of following the policies advised by Ross Innes and Cochrane. In particular, both had advised that leprosaria should be 'outward looking', extending their services into the district around, and not just waiting for patients to present themselves at the leprosarium for treatment. Although there had been a leprosy settlement in the District (first at Kawimbe from I9I5, and then at Kabalenge from i943) for very many years, the effect of setting up 'satellite' out-patients clinics manned by dressers trained in leprosy work can be seen in the sudden jump of new cases from 88 in 1953 to 459 in 1954.

Patients found on first examination to have positive smears were retained as in-patients at Kabalenge until negative; but all those bacillary negative and deemed suitable for out-patient treatment were treated $a b$ initio at the valley clinics, or were given a short period of 'stabilisation' of their treatment in Kabalenge Settlement, and then transferred to out-patient treatment at their nearest valley clinic.

Routine methods of treatment were used, Dapsone alone being available at first, but Thiacetazone, Thiambutosine, Solapsone, Ditophal, and I.N.H., being introduced as indicated during the later years of the campaign.

Treatment for leprosy, as throughout Zambia, is free of charge.

\section{S UMMAR Y}

A small but intensive campaign against leprosy in an area of high prevalence, carried out for ten years, is described. To serve a population of 5 I, ooo (of whom 2I, ooo were adults), there was one 'parent' Leprosy Settlement, and there were I 3 out-patient treatment centres. Seven of these latter mere manned by dressers who regularly visited the villages in their area as well as carrying out routine out-patient treatment.

Figures are given showing a steady decrease in new incidence of leprosy in the area annually, since the beginning of the campaign (1954). 
86 per I, ooo of the adult population have been treated for leprosy between 1953 and 1963 . Annual incidence rates for the years 1962 and I 963 have been only about 3 per i, ooo adults.

Traditional beliefs in the area are described, and what little can be traced about the history of leprosy in Zambia is set forth.

\section{A GKNOWLEDGEMENTS}

For information on the beliefs and customs of the people, I am gratef ul to Mr William Kawandami, now retired, and until recently the head artisan at Kabalenge Leprosy Settlement; and to Senior Medical Assistant Mr A. D. Musopelo and Medical Assistant Mr C. Mapulanga.

For records from I953 to I96I, I have used the clinical notes and admission books maintained under the supervision of Dr J. M. B. Garrod, (I954-I956), Dr H. Jocelyn Smyly (I957-I958), Dr E. J. Currant (I959-I96I), and Mr L. W. Corbridge, (who 'held the fort' as Superintendant during periods when there was no Leprologist).

To the Royal College of Physicians, London and the Royal Society of Tropical Medicine and Hygiene I am indebted for much help with reprints and photostat copies of articles on leprosy. I am especially grateful to $\mathrm{Mr} \mathrm{L}$. M. Payne, Librarian of the Royal College of Physicians, for a copy of the 'r 867 Report' and for much other contemporary material.

Officers of the Government Administrative service at Kawambwa have been very helpful with population figures.
I wish to thank Dr D. A. W. Rittey, Secretary for Health, Republic of Zambia, for permission to submit this article for publication.

\section{REFERENGES}

BAKER, E. (I 949). (unpublished). A report on a survey of Leprosy in the Northern District.

BRADSHAw. (1867). In Report on Leprosy by the Royal College of Physicians, London. p. 52.

browne, s. G. (i 962). Postgrad. Med. 7., 38, 87.

COChrane, R. G. (1932). Leprosy Rev., 3, 25-28.

COChrane, R. G. (I952). (unpublished). A report to the Director of Medical Services on Leprosy in Northern Rhodesia.

CUnNison, I. (1959). The Luapula Peoples of Northern Rhodesia, Manchester.

FEENY, P. (1 964). The Fight against Leprosy, London

GELFAND, M. (I 957). Livingstone the Doctor, Oxford.

Gelfand, M. (I96I). Northern Rhodesia in the days of the Charter, Oxford.

INNES, J. R. ( I 950). (unpublished). A report to the Director of Medical Services, Northern Rhodesia

innes, J. R. (1950). East Africa Med. F., 28, 2 I-28.

(1867). Lancet Editorial, $\mathbf{1}, 63$.

LAtapi, F., quoted by Frenken, J. H. (1963). Diffuse Le prosy of Lucio and Latapi, Oranjestad. p. 89.

milroy, G. (1867). Report on Leprosy by the Royal College of Physicians, London. p. 227.

mitchell, c. (1960). Rhodesia and Nyasaland, Salisbury. p. I 80 .

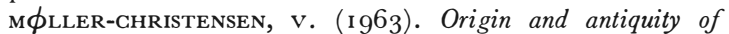
Leprosy, Eighth International Congress on Leprosy, Rio de Janeiro.

MUIR, E. (I 940). Leprosy Rev., I I, I 8-24.

PIzzI, м. (1952). W.H.O. Epidemiological and Vital Statistical Reports, Geneva., 5, 263-282.

World Health Organisation. (1959). Epidemiological and Vital Statistical Report, 12, 65. worsfold, J. T. (1957). Central African 7. of Med., 3, 362. WORSFOLD, J. T. (I 958). Leprosy Rev., 4, 222-226. White Fathers. (1 947). Bemba-English Dictionary, Chilubula. 